\title{
The role of uncoupling protein 2 and 3 genes polymorphism and energy expenditure in obese Indonesian children \\ by Mexitalia Setiawati Em
}

Submission date: 05-Dec-2018 01:32PM (UTC+0700)

Submission ID: 1051012853

File name: 2013_INT_Mexitalia_JPEM2013_UCP2_3.pdf (345.13K)

Word count: 5545

Character count : 25966 
Maria Mexitalia*, Taro Yamauchi, Agustini Utari, Damayanti R. Sjarif, Hertanto W. Subagio, Agustinus Soemantri and Takafumi Ishida

\section{The role of uncoupling protein 2 and 3 genes polymorphism and energy expenditure in obese Indonesian children}

Abstract

Aim: Uncoupling protein (UCP) genes, which may contribute to energy metabolism in mitochondria, may be involved in the pathogenesis of obesity. We analyzed the differences in energy expenditure between single nucleotide polymorphisms (SNPs) UCP3-55C/T, UCP3 Y210Y, and UCP2 A55V among Indonesian children.

Methods: The study included 76 schoolchildren ( 36 obese and 40 healthy; mean age, 12.8 years) in Semarang, Indonesia. Body composition was measured by bioelectrical impedance analysis; resting energy expenditure (REE) by indirect calorimetry; physical activity by uniaxial accelerometer; and total energy expenditure (TEE) by the equations extrapolated from REE and physical activity. UCP3-55C/T, UCP3 Y210Y, and UCP2 A55V were examined by restriction length fragment polymorphism analysis.

Results: The TEE of the subjects with the T/T genotype at $U C P 3-55 C / T$ after adjusting for fat-free mass $(63.2 \pm 7.2 \mathrm{kcal} /$ $\mathrm{kg} /$ day $)$ and T/T at $U C P 2 A 55 V(62.8 \pm 5.6 \mathrm{kcal} / \mathrm{kg} /$ day $)$ was lower than that of the subjects with the $\mathrm{C} / \mathrm{C}$ and $\mathrm{C} / \mathrm{T}$ genotypes $(p<0.05)$. The REE of the subjects with these $T / T$ genotypes tended to be lower than that of the subjects with $\mathrm{C} / \mathrm{C}$ and $\mathrm{C} / \mathrm{T}(\mathrm{p} \geq 0.05)$. No significant differences in REE or TEE were found between the UCP3 Y21OY genotypes.

Conclusions: The subjects with the $\mathrm{T} / \mathrm{T}$ genotypes of UCP3-55C/T or UCP2 A55V had lower TEE than those with other genotypes.

Keywords: children; energy expenditure; Indonesia; obesity; UCP genes.

*Corresponding author: Maria Mexitalia, Department of Pediatrics, Faculty of Medicine, Diponegoro University, Dr. Kariadi Hospital, Dr. Sutomo 16-18 Semarang Central Java 50231, Semarang, Indonesia, Phone/Fax: +62248414296. E-mail: maria_mexitalia@yahoo.com

Taro Yamauchi: Laboratory of Human Ecology, Graduate School of Health Sciences, Hokkaido University, Sapporo, Japan

Agustini Utari and Agustinus Soemantri: Department of Pediatrics, Faculty of Medicine, Diponegoro University, Dr. Kariadi Hospital, Semarang, Indonesia
Damayanti R. Sjarif: Department of Pediatrics, Faculty of Medicine, University of Indonesia, Dr. Cipto Mangunkusumo Hospital, Jakarta, Indonesia

Hertanto W. Subagio: Department of Nutrition, Faculty of Medicine, Diponegoro University, Semarang, Indonesia

Takafumi Ishida: Laboratory of Human Biology and Genetic, Department of Biological Sciences, Graduate School of Sciences, University of Tokyo, Tokyo, Japan

\section{Introduction}

Obesity is considered a global epidemic because its prevalence and severity in adults and children is increasing at an alarming rate worldwide $(1,2)$. Differences in energy metabolism may play a role in long-term body weight regulation and the pathogenesis of human obesity. The largest component of energy expenditure is resting energy expenditure (REE), which is the energy expended to maintain the basic physiological functions of the body. Meanwhile, physical activity is responsible for $25 \%$ to $31 \%$ of total energy expenditure (TEE) and is a key component of energy balance (3-5). The observed variations in body mass index (BMI) and fat mass may be genetically determined. Moreover, an increasing number of studies are reporting associations between DNA sequence variation in specific genes and obesity phenotypes $(6,7)$. Susceptibility to obesity is partly determined by genetic factors, but an obesity-promoting environment is typically necessary for their phenotypic expression. Such a genetically mediated susceptibility to environmental exposure is referred to as gene-environment interaction $(6,8)$. However, many genes are regulated in obesity, called polygenic genes $(7,9)$.

Uncoupling proteins (UCPs) are a family of mitochondrial transporters known to uncouple oxidative phosphorylation via proton leakage from the inner mitochondrial membrane. These mitochondrial proteins are implicated as potential regulators of thermoregulation and energy metabolism. More than five types of UCPs have been identified to date. UCP1 is expressed exclusively in brown adipose 
tissue and is responsible for thermogenesis in mammalian neonates and rodents; UCP2 is expressed in almost all mammalian tissues; $U C P 3$ is predominantly expressed in mammalian skeletal muscle and brown adipose tissue (9-11). In humans, UCP2 and UCP3 form a cluster on chromosome 11q13. The chromosomal location and tissue distribution patterns of UCP2 and UCP3 suggest that polymorphisms of these UCPs contribute to metabolic disorders via their major effects on energy metabolism $(12,13)$.

A number of polymorphisms have been identified in the UCP2 and UCP 3 genes, and their correlations with obesity-related phenotypes and body weight regulation have been evaluated in adult subjects. In particular, the $-55 \mathrm{C} / \mathrm{T}$ polymorphism of the $U C P 3$ gene and the $A 55 \mathrm{~V}$ polymorphism of the UCP2 gene are responsible for changes in UCP mRNA levels $(14,15)$, adult REE $(16,17)$, and weight gain. In addition, body fat percentage is genetically linked to the UCP2/UCP3 locus (18) and it is associated with oxidation rate and respiratory quotient $(\mathrm{RQ})(19,20)$ in populations with a marked susceptibility to obesity (21). The RQ of subjects with the homozygous $v / v$ at $A 55 \mathrm{~V}$ is higher than that of $\mathrm{A} / \mathrm{A}$ and $\mathrm{A} / \mathrm{V}$ subjects (20) and influences gross exercise efficiency (22). Other studies have failed to find relationships between UCP2 and UCP3, and energy expenditure $(18,23,24)$. Although a small number of studies have examined the effects of UCP variants on obesity in young children, some also report associations between UCP2 and $U C P 3$, and childhood obesity $(25,26)$. Such discrepancies in the literature may be attributable to differences in study design (e.g., population based vs. hospital based), selection and ascertainment schemes, sample sizes, or statistical analysis strategies (27). However, there is no study on the associations between energy expenditure and UCP2 and UCP3 involving Indonesian children. Therefore, we examined the roles of the polymorphisms of $U C P 3-55 C / T$, UCP3 Y210Y, and UCP2 A55V in energy expenditure in obese and non-obese Indonesian children.

\section{Subjects and methods}

A total of 76 subjects were included in this study. The study was conducted at a junior high school in Semarang City, Indonesia, from 2005 to 2007. The obese children were 11-15 years old, and lean agematched counterparts were recruited as controls. The study protocol was approved by the regional Ethical Committee, and informed consent was obtained from the parents of all the children.

We evaluated all of the students at the school and selected obese and lean subjects by simple random sampling. Body composition was measured by bioelectrical impedance analysis (BIA) Tanita TBF310 (Tanita Corp., Tokyo, Japan), which included weight and body fat, fat mass, and fat-free mass percentages. Studies have shown that differences of non-invasive methods to estimate fat mass such as dual-energy X-ray absorptiometry (DEXA), isotope dilution, BIA, and skinfold thickness had variations in marked body fat in children (28, 29). Considering the availability of the facility and the advantages of BIA for use in a large-scale study (28), we decided to measure the fat mass and calculate the fat-free mass by BIA. Height was measured by a mounted stadiometer. BMI was calculated as body weight $(\mathrm{kg})$ divided by height $(\mathrm{m})$ squared. Currently, there are no guidelines for classifying weight for children under 18 years in Indonesia or Indonesian standards for tracking growth in children, therefore, we used the CDC 2000 BMI growth chart. The cut-offs were as follows: children above the 95th percentile were classified as obese and those between the 5 th and 85 th percentiles were classified as healthy (i.e., controls).

\section{Energy expenditure}

REE was measured using an indirect calorimetry system (AR-1, Arco System, Chiba, Japan). REE was measured in the morning after 10-12 $\mathrm{h}$ of fasting in a temperature-controlled room over a single 5-min period. The energy values were measured using the Douglas bag technique. The resting metabolism rate was calculated as the mean of two values for lying down and sitting (30). Physical activity was measured using a 1-axial KenzLifecorder accelerometer. For each participant, a portable activity monitor based on a uniaxial accelerometry sensor (Lifecorder, Suzuken, Nagoya, Japan) was attached at the waist, and acceleration was recorded for 7 consecutive days. As it was small and light $(62 \times 46 \times 26 \mathrm{~mm}, 40 \mathrm{~g})$, the subjects were not disturbed by the machine (31). The accelerometer provided activity data every 2-min, as well as the step data. TEE was measured using equations combined from indirect calorimetry and accelerometer ( $\Sigma$ METs $\times$ min $\times$ measured REE). The sum of metabolic equivalents ( $\Sigma$ METs) was extrapolated from the accelerometer data according to a previous study (32).

\section{Genotyping}

DNA was extracted from blood samples. Genotyping was done using restriction fragment length polymorphism analysis at 3 polymorphic sites: UCP3-55C/T, UCP3 Y210Y, and UCP2 A55V. The DNA was amplified by polymerase chain reaction (PCR) with specific primers. The forward and reverse primers for the UCP3-55C/T sites were $5^{\prime}$-cct ccc ctc tca cct cac tg-3' and $5^{\prime}$-ggc act ggt ctt ata ccc ac- $3^{\prime}$, respectively. The 115-bp product was digested with BseDI. The C allele gave 94- and 21bp fragments, whereas the $\mathrm{T} / \mathrm{T}$ allele gave a 115-bp fragment. The forward and reverse primers for the silent mutation Y21OY (TAC $\rightarrow$ TAT) variant were $5^{\prime}$-tca agg aga agc $\operatorname{tgc} \operatorname{tgg}$ agt $-3^{\prime}$ and $5^{\prime}$-tac tag gca ctg ctt ctc tct ctg-3', respectively. The $Y 210$ (C) allele gave 110- and 20-bp fragments after being digested by the RsaI enzyme, and the Y21O(T) allele gave a 130-bp fragment. The forward and reverse primers for UCP2 A55V (GCC $\rightarrow$ GTC) were $5^{\prime}$-ctg gag tct cga tgg tgt ctac- $3^{\prime}$ and $5^{\prime}$ cac cgc ggt act ggg cgt tg- $3^{\prime}$, respectively. The 198-bp product was digested by the HincII restriction enzyme and gave 180- and 18-bp fragments for the $\mathrm{T}$ allele and a 198-bp fragment for the $\mathrm{C}$ allele. DNA fragments were resolved on a $4 \%$ agarose gel. The DNA extraction was done in the Center for Biomedical Research, Faculty of Medicine, Diponegoro University, Semarang, and the genotype analysis was done in the Laboratory of Human Biology and Genetics, Department 
of Biological Sciences, Graduate School of Sciences, University of Tokyo, Tokyo. Statistical analysis was performed using SPSS 11.0 (Chicago, IL, USA), and linkage disequilibrium was analyzed using the Haploview program (Broad Institute of MIT and Harvard; http:// www.broad.mit.edu/haploview/haploview).

\section{Results}

Seventy-six children, including 36 obese ( 25 boys and 11 girls) and 40 lean children (16 boys and 24 girls), with a mean age of 12.8 years, participated in this study. The characteristics of the study population are shown in Table 1. Both sexes of the obese subjects had higher REE, however, after adjusting for body weight, the obese subjects had lower REE/body weight. All the children were genotyped. There were 24,42 , and $10 \mathrm{C} / \mathrm{C}, \mathrm{C} / \mathrm{T}$, and $\mathrm{T} / \mathrm{T}$, respectively, on the $-55 C / T$ promoter region of UCP3. For the UCP3 $Y 210 Y$ genotyped at exon 5; 29, 41, and 56 children were $\mathrm{C} / \mathrm{C}, \mathrm{C} / \mathrm{T}$, and $\mathrm{T} / \mathrm{T}$, respectively. For UCP2 exon $4 \mathrm{A55V}$; 28 , 39 , and nine children were $\mathrm{C} / \mathrm{C}, \mathrm{C} / \mathrm{T}$, and $\mathrm{T} / \mathrm{T}$, respectively. All the polymorphisms at the promoter region and exons were in linkage disequilibrium (data not shown).

Table 2 and Figure 1 showed that the REE was lower in the subjects with the T/T genotypes of UCP3-55C/T and $U C P 2 A 55 \mathrm{~V}$, although the difference was not significant. Meanwhile, the results regarding the silent mutation of exon 5 UCP 3 were inconsistent. The subjects with $\mathrm{C} / \mathrm{T}$ had lower REE and TEE than those with other genotypes. The TEE, which was calculated on the basis of the REE and physical activity measured by an accelerometer, showed that the TEE of the T/T UCP2 A55V subjects was significantly lower $(2289 \pm 418 \mathrm{kcal} /$ day $)$ than those with the $\mathrm{C} / \mathrm{C}$ and $\mathrm{C} / \mathrm{T}$ genotypes. After adjusting for fat-free mass, the results regarding TEE/ffm/day were also similar: the subjects with T/T $(62.8 \pm 5.6 \mathrm{kcal} / \mathrm{kg} /$ day $)$ had lower TEE/ffm/day than those with $\mathrm{C} / \mathrm{C}(68.9 \pm 9.3$ $\mathrm{kcal} / \mathrm{kg} /$ day) and C/T (74.5 $\pm 19.8 \mathrm{kcal} / \mathrm{kg} /$ day $)$.

The REE of the obese subjects with the T/T genotype was lower than those of the obese subjects with the $\mathrm{C} / \mathrm{C}$ and $\mathrm{C} / \mathrm{T}$ genotypes, although the difference was not significant. In contrast, the obese children with the $\mathrm{C} / \mathrm{T}$ genotype of Y21OY UCP3 had the lowest TEE among all the genotypes, but the difference was also not significant. Similar results were found among the healthy children: the TEE of the subjects with the C/T Y210Y genotype was the lowest. The TEE/ffm/day of the subjects with $\mathrm{T} / \mathrm{T}$ on promoter UCP3-55C/T and UCP2 A55V was the lowest among all the genotypes; the difference was significant in the healthy children. These results indicate that in addition to REE, physical activity contributes to the energy expenditure in healthy children (Table 3).

\section{Discussion}

The subjects with a T/T genotype at the UCP3-55C/T and UCP2 A55V polymorphisms had lower TEE than those with the $\mathrm{C} / \mathrm{C}$ and $\mathrm{C} / \mathrm{T}$ genotypes. However, we did not find any association between the $\mathrm{T} / \mathrm{T}$ genotypes and REE, although the subjects with the $\mathrm{T} / \mathrm{T}$ genotypes had lower REE than those with other genotypes. The association between the UCP3-55C/T polymorphism and REE in various populations raises the hypothesis that this polymorphism modifies gene expression and therefore modulates energy homeostasis (33). The mitochondrial protein UCP3 is mainly expressed in skeletal muscle and possesses uncoupling activity (34). Pima Indians, who carry the $-55 \mathrm{~T}$ allele, have significantly higher UCP3 mRNA concentrations than those with the $-55 \mathrm{C} / \mathrm{C}$ allele. This indicates that the $-55 \mathrm{~T}$ allele can increase UCP 3 mRNA

Table 1 Subject characteristics.

\begin{tabular}{|c|c|c|c|c|}
\hline & \multicolumn{2}{|r|}{ Boys } & \multicolumn{2}{|r|}{ Girls } \\
\hline & Obese & Healthy & Obese & Healthy \\
\hline $\mathrm{n}$ & 25 & 16 & 11 & 24 \\
\hline Age, years & $12.8 \pm 0.3$ & $12.9 \pm 0.4$ & $12.6 \pm 0.5$ & $12.8 \pm 0.4$ \\
\hline Weight, kg & $66.2 \pm 7.7$ & $44.8 \pm 7.1$ & $68.1 \pm 10.9$ & $42.9 \pm 6.1$ \\
\hline Height, cm & $155.0 \pm 7.1$ & $156.5 \pm 8.0$ & $152.4 \pm 7.1$ & $151.1 \pm 6.1$ \\
\hline $\mathrm{BMI}, \mathrm{kg} / \mathrm{m}^{2}$ & $27.5 \pm 2.4$ & $18.2 \pm 1.7$ & $29.2 \pm 2.9$ & $18.7 \pm 1.9$ \\
\hline$\%$ fat & $32.3 \pm 10.9$ & $16.4 \pm 4.7$ & $38.3 \pm 4.4$ & $21.5 \pm 4.6$ \\
\hline REE/day, kcal & $2015 \pm 295$ & $1717 \pm 298$ & $1866 \pm 292$ & $1607 \pm 385$ \\
\hline REE/weight/day, kcal/kg & $30.6 \pm 3.5$ & $38.9 \pm 7.9$ & $27.5 \pm 2.2$ & $37.9 \pm 9.8$ \\
\hline TEE/day, kcal & $3131 \pm 486$ & $2558 \pm 482$ & $2832 \pm 547$ & $2427 \pm 609$ \\
\hline TEE/weight/day, kcal & $47.5 \pm 6.3$ & $58.4 \pm 15.1$ & $41.7 \pm 5.3$ & $57.3 \pm 15.4$ \\
\hline
\end{tabular}

BMI, body mass index; REE, resting energy expenditure; TEE, total energy expenditure. The values are mean \pm SD. 
Table 2 Genotype distribution and energy expenditure parameters.

\begin{tabular}{|c|c|c|c|c|c|}
\hline SNPS & Variables & $\mathrm{C} / \mathrm{C}$ & $\mathrm{C} / \mathrm{T}$ & $\mathbf{T} / \mathbf{T}$ & p-Value \\
\hline \multirow[t]{7}{*}{$U C P 3-55 C / T$} & $\mathrm{n}$ & 24 & 42 & 10 & \\
\hline & REE/day, kcal & $1836 \pm 302$ & $1820 \pm 418$ & $1641 \pm 188$ & 0.140 \\
\hline & REE/weight/day, kcal/kg & $32.6 \pm 5.9$ & $35.5 \pm 9.6$ & $32.5 \pm 5.3$ & 0.267 \\
\hline & $\mathrm{REE} / \mathrm{ffm} / \mathrm{day}, \mathrm{kcal} / \mathrm{kg}$ & $46.2 \pm 7.8$ & $47.9 \pm 11.1$ & $42.4 \pm 4.2$ & 0.167 \\
\hline & TEE/day, kcal & $2754 \pm 498$ & $2809 \pm 684$ & $2455 \pm 413$ & 0.262 \\
\hline & TEE/weight/day, kcal/kg & $48.9 \pm 8.3$ & $54.8 \pm 15.9$ & $48.2 \pm 7.0$ & 0.146 \\
\hline & $\mathrm{TEE} / \mathrm{ffm} /$ day, $\mathrm{kcal} / \mathrm{kg}$ & $69.3 \pm 12.2$ & $74.0 \pm 18.3$ & $63.2 \pm 7.2$ & $0.044^{\mathrm{a}}$ \\
\hline \multirow[t]{7}{*}{ UCP3 Y $210 Y$} & $\mathrm{n}$ & 29 & 41 & 6 & \\
\hline & REE/day, kcal & $1864 \pm 409$ & $1766 \pm 344$ & $1742 \pm 238$ & 0.395 \\
\hline & REE/weight/day, kcal/kg & $35.0 \pm 11.8$ & $33.6 \pm 4.9$ & $34.1 \pm 4.6$ & 0.637 \\
\hline & $\mathrm{REE} / \mathrm{ffm} /$ day, $\mathrm{kcal} / \mathrm{kg}$ & $49.3 \pm 13.9$ & $45.2 \pm 5.2$ & $44.4 \pm 1.7$ & 0.790 \\
\hline & TEE/day, kcal & $2867 \pm 697$ & $2650 \pm 545$ & $2803 \pm 475$ & 0.340 \\
\hline & TEE/weight/day, kcal/kg & $53.8 \pm 18.9$ & $50.4 \pm 8.3$ & $54.6 \pm 5.3$ & 0.423 \\
\hline & $\mathrm{TEE} / \mathrm{ffm} / \mathrm{day}, \mathrm{kcal} / \mathrm{kg}$ & $75.6 \pm 22.4$ & $67.8 \pm 9.4$ & $71.3 \pm 4.5$ & 0.329 \\
\hline \multirow[t]{7}{*}{ UCP2 A55V } & $\mathrm{n}$ & 28 & 39 & 9 & \\
\hline & REE/day, kcal & $1848 \pm 391$ & $1822 \pm 359$ & $1571 \pm 198$ & 0.058 \\
\hline & REE/weight/day, kcal/kg & $32.8 \pm 5.7$ & $35.0 \pm 10.1$ & $34.6 \pm 4.5$ & 0.385 \\
\hline & $\mathrm{REE} / \mathrm{ffm} /$ day, $\mathrm{kcal} / \mathrm{kg}$ & $45.4 \pm 6.7$ & $48.4 \pm 11.8$ & $43.3 \pm 1.4$ & 0.218 \\
\hline & TEE/day, kcal & $2816 \pm 632$ & $2799 \pm 588$ & $2289 \pm 418$ & $0.019^{\mathrm{a}}$ \\
\hline & TEE/weight/day, kcal/kg & $50.0 \pm 7.9$ & $54.0 \pm 16.8$ & $50.1 \pm 6.9$ & 0.812 \\
\hline & $\mathrm{TEE} / \mathrm{ffm} /$ day, $\mathrm{kcal} / \mathrm{kg}$ & $68.9 \pm 9.3$ & $74.5 \pm 19.8$ & $62.8 \pm 5.6$ & $0.021^{\mathrm{a}}$ \\
\hline
\end{tabular}

BMI, body mass index; REE, resting energy expenditure; REE/ffm/day, REE/fat-free mass/day; TEE, total energy expenditure; TEE/ffm/day, $\mathrm{TEE} /$ fat-free mass/day. The values are mean \pm SD. Kruskal-Wallis test (non-parametric data).

asignificantly different from $\mathrm{T} / \mathrm{T}$ at $\mathrm{p}<0.05$.

expression more than the $-55 \mathrm{C}$ allele (15). In contrast, in the present study, the subjects carrying the $-55 \mathrm{~T} / \mathrm{T}$ genotype had lower TEE than those with $\mathrm{C} / \mathrm{C}$ and $\mathrm{C} / \mathrm{T}$. A study on Danish men assessed the role of physical activity as an effect modifier in the UCP3-55C/T polymorphism (23), although there was no evidence of interaction between the UCP variants and physical activity. However, a study in the Spanish population found that the UCP3-55C/T polymorphism is associated with a lower risk of obesity when recreational energy expenditure was taken into consideration. The possible explanation for this finding is similar to that of a previous study: decreasing UCP3 expression in the $-55 C / T$ polymorphism increases energy expenditure associated with physical activity (27). As a result of the contribution of energy from physical activity to the TEE, we assumed that physical activity plays a role in a variety of $U C P 3-55 C / T$ polymorphisms.

The UCP3 Y210Y polymorphism was not associated with energy expenditure. The genotype frequency of the UCP3 Y21OY polymorphism in the present study was comparable between the obese and healthy subjects, concordant with the Quebec Family study (35) and Heritage
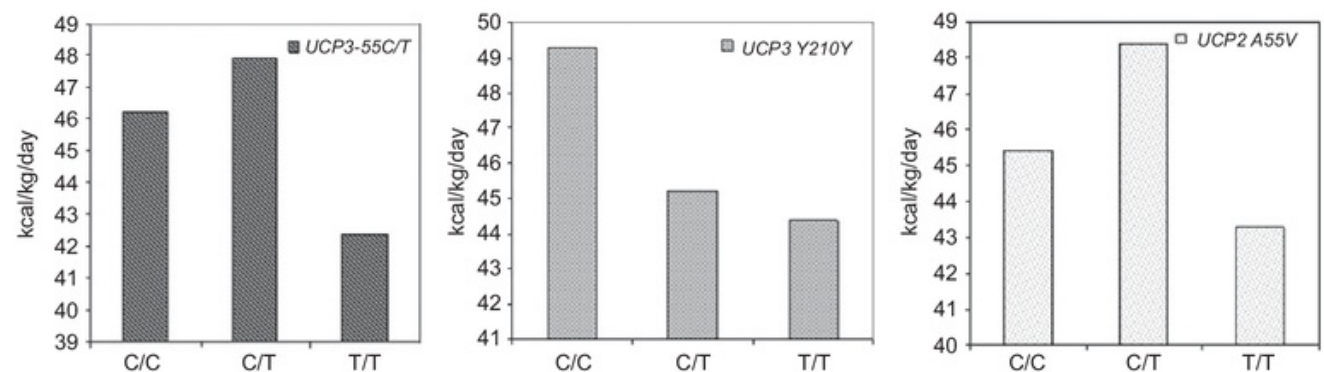

Figure 1 Resting energy expenditure (REE) after adjusting for fat-free mass. * ${ }^{*}$ ignificantly different from $\mathrm{T} / \mathrm{T}$ at the $U C P 3-55 C / T$ and $U C P 2$ A55V at $\mathrm{p}<0.05$. 
Table 3 Genotype distribution and energy expenditure parameters in obese and normal subjects

\begin{tabular}{|c|c|c|c|c|c|c|c|}
\hline \multirow[t]{2}{*}{ SNPs } & & \multicolumn{3}{|r|}{ Obese } & \multicolumn{3}{|r|}{ Non-obese } \\
\hline & & $\mathrm{C} / \mathrm{C}$ & $\mathrm{C} / \mathrm{T}$ & $T / T$ & $\mathrm{C} / \mathrm{C}$ & $C / T$ & $T / T$ \\
\hline \multirow[t]{7}{*}{$U C P 3 \cdot 55 C / T$} & $\mathrm{n}$ & 13 & 19 & 4 & 11 & 23 & 6 \\
\hline & REE/day, kcal & $2013 \pm 228$ & $1967 \pm 362$ & $1829 \pm 91$ & $1626 \pm 242$ & $1698 \pm 429$ & $1515 \pm 107$ \\
\hline & REE/weight/day, kcal/kg & $29.3 \pm 3.9$ & $30.0 \pm 3.6$ & $28.0 \pm 3.5$ & $36.3 \pm 6.2$ & $39.9 \pm 10.8$ & $35.5 \pm 4.0$ \\
\hline & $\mathrm{REE} / \mathrm{ffm} / \mathrm{day}, \mathrm{kcal} / \mathrm{kg}$ & $47.1 \pm 8.4$ & $45.7 \pm 6.3$ & $40.9 \pm 6.1$ & $45.2 \pm 7.3$ & $49.8 \pm 13.7$ & $43.5 \pm 2.6$ \\
\hline & TEE/day, kcal & $3060 \pm 417$ & $3066 \pm 618$ & $2848 \pm 266$ & $2393 \pm 311$ & $2596 \pm 675$ & $2193 \pm 240$ \\
\hline & TEE/weight/day, kcal/kg & $44.8 \pm 5.9$ & $46.8 \pm 7.0$ & $43.7 \pm 7.13$ & $53.7 \pm 8.3$ & $61.3 \pm 18.2$ & $51.2 \pm 5.5$ \\
\hline & $\mathrm{TEE} / \mathrm{ffm} / \mathrm{day}, \mathrm{kcal} / \mathrm{kg}$ & $71.6 \pm 14.4$ & $70.8 \pm 9.6$ & $63.6 \pm 9.7$ & $66.5 \pm 8.8$ & $76.5 \pm 23.2$ & $62.9 \pm 6.2^{\mathrm{a}}$ \\
\hline \multirow[t]{7}{*}{ UCP3 Y210Y } & $\mathrm{n}$ & 15 & 18 & 3 & 14 & 23 & 3 \\
\hline & REE/day, kcal & $1999 \pm 263$ & $1952 \pm 350$ & $1926 \pm 123$ & $1720 \pm 493$ & $1621 \pm 264$ & $1557 \pm 157$ \\
\hline & REE/weight/day, kcal/kg & $29.3 \pm 3.3$ & $29.7 \pm 3.2$ & $30.7 \pm 3.3$ & $41.1 \pm 14.4$ & $36.6 \pm 3.6$ & $37.6 \pm 2.5$ \\
\hline & $\mathrm{REE} / \mathrm{ffm} /$ day, $\mathrm{kcal} / \mathrm{kg}$ & $47.7 \pm 8.4$ & $44.4 \pm 6.3$ & $43.3 \pm 0.4$ & $51.0 \pm 18.3$ & $45.8 \pm 4.2$ & $45.5 \pm 1.8$ \\
\hline & $\mathrm{TEE} /$ day, kcal & $3099 \pm 493$ & $2966 \pm 568$ & $3187 \pm 345$ & $2619 \pm 811$ & $2402 \pm 381$ & $2419 \pm 65$ \\
\hline & TEE/weight/day, kcal/kg & $45.5 \pm 7.4$ & $45.1 \pm 6.1$ & $50.5 \pm 3.7$ & $62.6 \pm 23.3$ & $54.6 \pm 7.5$ & $58.6 \pm 2.9$ \\
\hline & $\mathrm{TEE} / \mathrm{ffm} / \mathrm{day}, \mathrm{kcal} / \mathrm{kg}$ & $73.7 \pm 13.6$ & $67.3 \pm 10.0$ & $71.5 \pm 3.9$ & $77.7 \pm 29.5$ & $68.2 \pm 9.2$ & $71.1 \pm 6.0$ \\
\hline \multirow[t]{7}{*}{ UCP2 A55V } & $\mathrm{n}$ & 15 & 19 & 2 & 13 & 20 & 7 \\
\hline & REE/day, kcal & $2071 \pm 380$ & $1905 \pm 208$ & $1824 \pm 192$ & $1590 \pm 206$ & $1743 \pm 451$ & $1499 \pm 137$ \\
\hline & REE/weight/day, kcal/kg & $30.0 \pm 3.6$ & $29.4 \pm 3.3$ & $28.8 \pm 5.4$ & $36.1 \pm 6.0$ & $40.4 \pm 11.4$ & $36.2 \pm 2.7$ \\
\hline & $\mathrm{REE} / \mathrm{ffm} / \mathrm{day}, \mathrm{kcal} / \mathrm{kg}$ & $45.7 \pm 6.6$ & $45.9 \pm 7.9$ & $43.1 \pm 0.1$ & $45.1 \pm 7.1$ & $50.7 \pm 14.4$ & $43.3 \pm 1.6$ \\
\hline & $\mathrm{TEE} /$ day, kcal & $3191 \pm 619$ & $2947 \pm 404$ & $2789 \pm 632$ & $2383 \pm 268$ & $2659 \pm 704$ & $2146 \pm 242^{a}$ \\
\hline & TEE/weight/day, kcal/kg & $46.3 \pm 6.9$ & $45.4 \pm 0.59$ & $44.2 \pm 13.5$ & $54.0 \pm 7.1$ & $62.2 \pm 19.7$ & $51.8 \pm 4.2$ \\
\hline & $\mathrm{TEE} / \mathrm{ffm} /$ day, kcal/kg & $70.3 \pm 10.7$ & $70.9 \pm 12.8$ & $65.5 \pm 8.2$ & $67.4 \pm 7.6$ & $77.9 \pm 24.6$ & $62.0 \pm 5.3^{3}$ \\
\hline
\end{tabular}

BMI, body mass index; REE, resting energy expenditure; REE/ffm/day, REE/fat-free mass/day; TEE, total energy expenditure; TEE/ffm/day, $\mathrm{TEE} /$ fat-free mass/day. The values are mean $\pm \mathrm{SD}$. Kruskal-Wallis test (non-parametric data).

aSignificantly different from $\mathrm{T} / \mathrm{T}$ at $\mathrm{p}<0.05$.

cohort study (36). Both studies found that the UCP3 Y210Y polymorphism is not associated with adiposity (35) and did not contribute to adiposity $y_{8}$ after 20 weeks of endurance training (36). UCP Y210Y is a silent mutation that is not expected to alter the function of the UCP3 protein, as found in the present study. In contrast, a previous study on racial differences regarding the relationship between uncoupling protein genes and REE found that the REE values of African-American women with the $\mathrm{C} / \mathrm{C}$ genotype of UCP3 Y210Y are significantly lower than those of Caucasian women with the same genotype (21). No variation in REE was observed with respect to $-55 C / T$, but the REE was significantly lower in subjects with the $\mathrm{C} / \mathrm{C}$ genotype of $Y 210 Y$ than in those with the T/T genotype (23). Thus, the inconsistencies among some studies indicate that the silent mutation may only play a role in specific populations.

The UCP2 A55V in exon 4 is one of the most commonly studied variants. This variant is reported to be associated with the sleeping metabolic rate (17), energy expenditure adjusted for fat-free mass, fat mass, spontaneous physical activity (20), and exercise efficiency while bicycling
(22). Astrup et al. (20) report that 24-h energy expenditure adjusted for fat-free mass, fat mass, and spontaneous physical activity is lower in subjects with the T/T genotype than those with other genotypes. Similarly, the 24-h RQ adjusted for energy balance, age, sex, and spontaneous physical activity is higher in subjects with $\mathrm{T} / \mathrm{T}$ than those with $\mathrm{C} / \mathrm{C}$ and $\mathrm{C} / \mathrm{T}$ genotypes. Therefore, subjects with the UCP2 T/T genotype exhibit enhanced metabolic efficiency and lower fat oxidation compared with those with other genotypes. The present result shows that the subjects with the T/T genotype had lower REE and TEE than those with the $\mathrm{C} / \mathrm{C}$ and $\mathrm{C} / \mathrm{T}$ genotypes, although only TEE was significantly lower (20). This indicates that physical activity contributes to TEE, which we will analyze in further detail. On the contrary, a study on childhood obesity reports no significant associations between UCP2 A55V and BMI or body composition. The exon $4 \mathrm{C}$ to $\mathrm{T}$ variant at amino acid 55 seems to be of a little or no importance in the regulation of child and adult body weight (18). A study of young Korean children found that subjects with the T/T genotype of UCP2 A55V have a lower BMI than those with the $\mathrm{C} / \mathrm{C}$ and $\mathrm{C} / \mathrm{T}$ genotypes. Ethnic differences in body weight and 
fat distribution, and gene polymorphism frequencies may possibly explain these discrepancies.

The small number of subjects that participated in our study may not be able to give the definite conclusion. However, this was the first preliminary study about the uncoupling protein genes in relation with energy expenditure in obese Indonesian children. This study suggests that the subjects with the T/T genotypes of UCP3-55C/T and UCP2 A55V have lower TEE than those with other genotypes. Despite the shown result on the metabolic efficiency, the contribution of physical activity to TEE needs to be further studied.

Received October 4, 2012; accepted December 22, 2012

\section{References}

1. Haslam DW, James WP. Obesity. Lancet 2005;366:1197-209.

2. Koletzko B, Girardet JP, Klish W, Tabacco O. Obesity in children and adolescents worldwide: current views and future directions - working group report of the first World Congress of Pediatric Gastroenterology, Hepatology, and Nutrition. J Pediatr Gastroenterol Nutr 2002;35:S205-12.

3. FAO, Food and Nutrition Technical Report Series. Human energy requirements. Report of a joint FAO/WHO/UNU Expert Consultation. Rome: FAO, 2001:17-24.

4. Goran M. Measurement issues related to studies of childhood obesity: assessment of body composition, body fat distribution, physical activity, and food intake. Pediatrics 1998;101:505-18.

5. Kohl III HW, Hobbs KE. Development of physical activity behaviors among children and adolescents. Pediatrics 1998;101:549-55.

6. Clement K, Ferre P. Genetics and pathophysiology of obesity. Pediatr Res 2003;53:721-5.

7. Rankinen T, Zuberi A, Chagnon YC, Weisnagel SJ, Argyropoulos $\mathrm{G}$, et al. The human obesity gene map: the 2005 update. Obesity 2006;14:529-644.

8. Li S, Loos RJ. Progress in the genetics of common obesity: size matters. Curr Opin Lipidol 2008;19:113-21.

9. Nedergaard J, Cannon B. The novel uncoupling protein UCP2 and UCP3: what do they really do? Pros and cons for suggested functions. Exp Physiol 2003;88:65-84.

10. Nubel T, Ricquier D. Respiration under control of uncoupling proteins: clinical perspective. Horm Res 2006;65:300-10.

11. Sudoyo $\mathrm{H}$. Uncoupling protein (UCP) dan metabolisme energi. In: Tjokroprawiro A, Soegih R, Soegondo S, Wijaya A, Sutardjo B, et al., editors. The 3rd National Obesity Symposium. Jakarta: ISSO, 2004:15-30.

12. Dalgaard LT, Pedersen 0 . Uncoupling proteins: functional characteristics and role in the pathogenesis of obesity and type II diabetes. Diabetologia 2001;40:946-65.

13. Urhammer SA, Dalgaard LT, Sorensen TI, Tybjaerg-Hansen A, Echwald SM, et al. Organisation of the coding exons and mutational screening of the uncoupling protein 3 gene in subjects with juvenile-onset obesity. Diabetologia 1998;41:241-4.

14. Kovacs P, Ma L, Hanson RL, Franks P, Stumvoll M, et al. Genetic variation in UCP2 (uncoupling protein-2) is associated with energy metabolism in Pima Indians. Diabetologia 2005;48:2292-5.

15. Schrauwen P, Xia J, Bogardus C, Prately RE, Ravussin E. Skeletal muscle uncoupling protein 3 expression is a determinant of energy expenditure in Pima Indians. Diabetes 1999;48:146-9.
16. Bouchard C, Perusse L, Chagnon YC, Warden C, Ricquier D. Linkage between markers in the vicinity of the uncoupling protein 2 gene and resting metabolic rate. Hum Mol Genet 1997;6:1887-9.

17. Walder K, Norman RA, Hanson RL, Schrauwen P, Neverova M, et al. Association between uncoupling protein polymorphisms (UCP2-UCP3) and energy metabolism/obesity in Pima Indians. Human Mol Genet 1998;7:1431-5.

18. Yanovski JA, Diament AL, Sovik KN, Nguyen TT, Li H, et al. Associations between uncoupling protein 2, body composition, and resting energy expenditure in lean and obese African American, Caucasian, and Asian children. Am J Clin Nutr 2000;71:1405-12.

19. Argyropoulos G, Brown AM, Willi SM, Zhu J, He Y, et al. Mutations in the human uncoupling protein 3 gene on the respiratory quotient and fat oxidation in severe obesity and type 2 diabetes. J Clin Invest 1998;102:1345-51.

20. Astrup A, Toubro S, Dalgaard LT, Urhammer SA, Sorensen TI, et al. Impact of the $v / v 55$ polymorphism of the uncoupling protein 2 gene on 24-h energy expenditure and substrate oxidation. Int J Obes 1999;23:1030-4.

21. Kimm SY, Glynn NW, Aston CE, Damcott CM, Poehlman ET, et al. Racial differences in the relation between uncoupling protein genes and resting energy expenditure. Am J Clin Nutr 2002;75:714-9.

22. Buemann B, Schierning B, Toubro S, Bibby BM, Sorensen T, et al. The association between the val/ala-55 polymorphism of the uncoupling protein 2 gene and exercise efficiency. Int J Obes 2001;25:467-71.

23. Berentzen T, Dalgaard LT, Petersen L, Pedersen O, Sorensen TI. Interaction between physical activity and variants of the genes encoding uncoupling proteins- 2 adn- 3 in relation to body weight changes during a 10-y follow-up. Int J Obes 2005;29:93-9.

24. Chung WK, Luke A, Cooper RS, Rotini C, Vidal-Puig A, et al. Genetic and physiologic analysis of the role of uncoupling protein 3 in human energy homeostasis. Diabetes 1999;48:1890-5.

25. Jun HS, Kim IK, Lee HJ, Lee HJ, Kang JH, et al. Effects of UCP2 and UCP 3 variants on the manifestation of overweight in Korean children. Obesity 2009;17:355-62.

26. Ochoa MC, Santos JL, Azcona C, Moreno-Aliaga MJ, MartınnezGonzalez MA, et al. Association between obesity and insulin resistance with UCP2-UCP3 gene variants in Spanish children and adolescents. Mol Genet Metab 2007;92:351-8.

27. Alonso A, Marti A, Corbalan MS, Martinez-Gonzales MA, Forga $\mathrm{L}$, et al. Association of UCP3 gene $-55 \mathrm{C} / T$ polymorphism 
and obesity in a Spanish population. Ann Nutr Metab 2005;49:183-8.

28. Hosking J, Metcalf BS, Jeffery AN, Voss LD, Wilkin TJ. Validation of foot-to-foot bioelectrical impedance analysis with dual-energy X-ray absorptiometry in the assessment of body composition in young children: the EarlyBird cohort. Br J Nutr 2006;96:1163-8.

29. L'Abee C, Visser GH, Liem WT, Kok DE, Sauer PJ, et al. Comparison of methods to assess body fat in non-obese six to seven-year-old children. ClinNutr 2010;29:317-22.

30. Yamauchi T, Ohtsuka R. Basal metabolic rate and energy costs at rest and during exercise in rural- and urban-dwelling Papua New Guinea Highlanders. Eur J Clin Nutr 2000;54: 494-9.

31. Yamauchi T, Kim SN, Lu Z, Ichimaru N, Maekawa R, et al. Age and gender differences in the physical activity patterns of urban schoolchildren in Korea and China. J Physiol Anthropol 2007;26:101-7.
32. Kumahara H, Schutz Y, Ayabe M, Yoshioka M, Yoshitake Y, et al. The use of uniaxial accelerometry for the assessment of physicalactivity-related energy expenditure: a validation study against whole-body indirect calorimetry. Br J Nutr 2004;91:235-43.

33. Liu YJ, Liu PY, Long J, Lu Y, Elze L, et al. Linkage and association analyses of the UCP3 gene with obesity phenotypes in Caucasian families. Physiol Genomics 2005;22:197-203.

34. Argyropoulos G, Harper ME. Molecular biology of thermoregulation. Invited review: uncoupling proteins and thermoregulation. J Appl Physiol 2002;92:2187-98.

35. Lanouette CM, Giacobino JP, Pérusse L, Lacaille M, Yvon C, et al. Association between uncoupling protein 3 gene and obesityrelated phenotypes in the Québec family study. Mol Med 2001;7:433-41.

36. Lanouette CM, Chagnon YC, Rice T, Perusse L, Muzzin P, et al. Uncoupling protein 3 gene is associated with body composition changes with training in Heritage study. J Appl Physiol 2002;92:1111-8. 
The role of uncoupling protein 2 and 3 genes polymorphism and energy expenditure in obese Indonesian children

ORIGINALITY REPORT

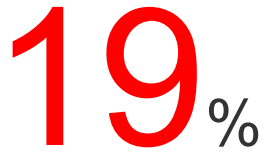

SIMILARITY INDEX

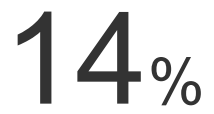

INTERNET SOURCES
$19 \%$

PUBLICATIONS
$1 \%$

STUDENT PAPERS

PRIMARY SOURCES

1

Cha, M.H.. "Association of UCP2 and UCP3

gene polymorphisms with serum high-density lipoprotein cholesterol among Korean women",

Metabolism, 200706

Publication

2 www.ncbi.nlm.nih.gov Internet Source

3 Kotoko Kosuge. "Human uncoupling protein 2 and 3 genes are associated with obesity in Japanese", Endocrine, 12/2008

Publication

4 Www.nature.com

Internet Source

5 discovery.dundee.ac.uk

Internet Source

6 www.deepdyve.com Internet Source

Tuomo Rankinen. "The Human Obesity Gene 
Map: The 2001 Update", Obesity, 03/2002

Alvaro Alonso, Amelia Martí, María Soledad

Corbalán, Miguel A. Martínez-González, Luis

Forga, J. Alfredo Martínez. "Association of

UCP3 Gene -55C>T Polymorphism and

Obesity in a Spanish Population", Annals of

Nutrition and Metabolism, 2005

Publication

$10 \quad$ www.jstage.jst.go.jp

Internet Source

11 physiolgenomics.physiology.org

Internet Source

12 udspace.udel.edu Internet Source

13 www.wjgnet.com

Internet Source

14 www-personal.umich.edu Internet Source

15 "Track 1 - Track 5", International Journal of Obesity, 05/2008 


\section{The role of uncoupling protein 2 and 3 genes polymorphism and energy expenditure in obese Indonesian children}

GRADEMARK REPORT

FINAL GRADE

10

\section{PAGE 1}

PAGE 2

PAGE 3

PAGE 4

PAGE 5

PAGE 6

PAGE 7
GENERAL COMMENTS

Instructor 